\title{
XXXVI. Additional note on conical refraction
}

\section{J. MacCullagh F.T.C.D.}

To cite this article: J. MacCullagh F.T.C.D. (1833) XXXVI. Additional note on conical refraction , Philosophical Magazine Series 3, 3:15, 197-197, DOI: 10.1080/14786443308648156

To link to this article: http://dx.doi.org/10.1080/14786443308648156

册 Published online: 01 Jun 2009.

Submit your article to this journal $\pi$

Џ Article views: 2

Q View related articles $₫$ 
measuring about $\frac{1}{10}$ th of an inch in diameter; it is usually placed under stones and in crevices of the earth.

There must be something very remarkable in the internal as well as external organization of this extraordinary spider, for numerous specimens of both sexes submerged in cold water on the 21 st of October 1892, remained in that situation till the 22nd of November, an interval of 768 hours, without having their vital energies suspended. It is evident, therefore, that this species possesses the power of abstracting respirable air from water, for though in the act of submersion the spiracles are usually enveloped in a bubble of air, yet so small a supply must soon be exhausted, and, indeed, it speedily disappears.

Oakland, near Ilanwrst, Denbighshire, July $29,1833$.

XXXVI. Additional Note on Conical Refraction. By J. MacCullagh, F.T.C.D.

To the Editors of the Philosophical Magazine and Journal.

Gentlemen,

THE introductory part of my note which appeared in your 1 last Number was written in haste, and I have reason to think it may not be rightly understood. You will therefore allow me to add a few observations that seem to be wanting.

The principal thing pointed out in the paper that I published some time ago in the Transactions of the Royal Irish Academy, is a very simple relation between the tangent planes of Fresnel's wave surface and the sections of two reciprocal ellipsoids. Now this relation depends upon the axes of the sections, and therefore naturally suggested to me the peculiar cases of circular section in which every diameter is an axis. Thus a new inquiry was opened to my mind. And accordingly, without caring just then to obtain final results, which seemed to be an easy matter at any time, I expressed in conversation my intention of returning to the subject of Fresnel's theory, in a supplementary paper. The design was interrupted, and I was prevented from attending to it again, until I was told that Professor Hamilton had discovered cusps and circles of contact on the wave surface. This reminded me of the cases of circular section, and the details given in $\mathrm{my}$ last note were immediately deduced. I am, Gentlemen, \&c. J. MacCullagh.

Trinity College, Dublin, August 16, 1833. 